\title{
Non-Obstructed Megaureter
}

National Cancer Institute

\section{Source}

National Cancer Institute. Non-Obstructed Megaureter. NCI Thesaurus. Code C123189.

A meg aureter in which there is no obstruction at the ureterovesical junction. 